\title{
Modelling tempo-spatial signatures of Heinrich Events: influence of the climatic background state
}

\author{
Matthias Prange*, Gerrit Lohmann, Vanya Romanova, Martin Butzin \\ DFG Research Center Ocean Margins (RCOM) and Department of Geosciences, University of Bremen, Klagenfurterstr., Bremen 28334, Germany
}

Received 2 September 2003; accepted 10 November 2003

\begin{abstract}
Different sea surface temperature (SST) reconstructions for the Last Glacial Maximum are applied to a hybrid-coupled climate model. The resulting oceanic states are perturbed by North Atlantic meltwater inputs in order to simulate the effect of Heinrich Events on the Atlantic thermohaline circulation (THC) and SST. The experiments show that both the Atlantic SST signature of the meltwater event and the time span of THC recovery strongly depend on the climatic background state. Data-model comparison reveals that the overall spatial signature of SST anomalies is captured much better in the glacial meltwater experiments than in an analogous experiment under present-day conditions. In particular, a breakdown of the modern THC would induce a much stronger temperature drop in high northern latitudes than did Heinrich Events during the ice age. Moreover, our results suggest that the present-day circulation can settle into a stable 'off' mode, whereas the glacial THC was mono-stable. Mono-stability may serve as an explanation for the recovery of the THC after Heinrich Event shutdowns during the Last Glaciation.
\end{abstract}

(C) 2003 Elsevier Ltd. All rights reserved.

\section{Introduction}

Transporting heat over large distances, the Atlantic thermohaline circulation (THC) plays a key role in the climate system. Geological records from the last glacial period suggest that enhanced abundances of ice-rafted debris in the North Atlantic (Heinrich Events) were associated with shutdowns of the THC and global-scale climatic changes (e.g., Broecker and Hemming, 2001; Clark et al., 2002). The concept of THC fluctuations with global impact has motivated a large number of ocean and climate modellers to simulate THC disruptions by injecting freshwater to the North Atlantic (e.g., Bryan, 1986; Maier-Reimer and Mikolajewicz, 1989; Stocker and Wright, 1991; Manabe and Stouffer, 1995; Rahmstorf, 1995; Lohmann et al., 1996; Schiller et al., 1997; Crucifix et al., 2001; Ganopolski and Rahmstorf, 2001; Rind et al., 2001; Lohmann, 2003). These model results suggest that the THC is highly sensitive to changes in the North Atlantic freshwater budget, such that anomalous freshwater inputs can trigger a collapse of the circulation, thereby causing an abrupt tempera-

\footnotetext{
*Corresponding author. Tel.: + 49-421-218-7187; fax: + 49-421-2187040.

E-mail address: mprange@palmod.uni-bremen.de (M. Prange).
}

ture drop in the order of $5-10^{\circ} \mathrm{C}$ in the North Atlantic realm.

Even though the combined efforts of palaeoceanographers and climate modellers are well on the way to providing a consistent picture about the climatic impact of Heinrich Events and the important role of the THC, a closer inspection still reveals a number of discrepancies between geological data and model results. Here, we highlight the importance of the climatic background state for the spatial pattern of sea surface temperature (SST) change in response to a THC shutdown. In the model studies mentioned above, freshwater perturbations were applied either to non-glacial states or to highly simplified, zonally averaged models of the ocean. Utilizing an atmosphere general circulation model (AGCM) in combination with an ocean general circulation model (OGCM) in a hybrid-coupled framework, we demonstrate that important features of the Heinrich Event tempo-spatial signature in the Atlantic Ocean can only be simulated by perturbing a glacial state of the ocean.

\section{Glacial climate simulations with an AGCM}

We employ three different SST reconstructions for the Last Glacial Maximum to force the AGCM ECHAM3/ 
T42 (Roeckner et al., 1992): (1) The CLIMAP (1981) reconstruction with an additional cooling of $3^{\circ} \mathrm{C}$ in the tropics (Lohmann and Lorenz, 2000), (2) the North Atlantic reconstruction by Weinelt et al. (1996) merged with CLIMAP (Schäfer-Neth and Paul, 2001) and (3) the new GLAMAP 2000 Atlantic reconstruction (Sarnthein et al., 2003) combined with CLIMAP as described by Paul and Schäfer-Neth (2003). As compared to CLIMAP, the North Atlantic sea-ice cover is substantially reduced in the newer reconstructions. The GLAMAP winter sea-ice margin is similar to CLIMAP's summer sea-ice boundary, and the Nordic Seas are ice-free during summer. Consistent with the reduced sea-ice extent, the new reconstructions provide higher SSTs in the northern North Atlantic than CLIMAP.

The three glacial experiments are denoted as experiments C ('C'LIMAP), W ('W'einelt) and G ('G'LAMAP). Orbital forcing, reduced concentration of carbon dioxide (200 ppm), and topographic changes (Peltier, 1994) are taken into account (cf. Lohmann and Lorenz, 2000). A fourth experiment, PD, is carried out with present-day forcing. Fig. 1 shows simulated North Atlantic surface air temperatures for the three glacial experiments relative to experiment PD. As a result of the excessive sea-ice cover and the additional tropical cooling, experiment $\mathrm{C}$ provides the coldest climate. For a detailed description of the simulated glacial climates, including analysis of the hydrologic cycle, we refer to Lohmann and Lorenz (2000) and Romanova et al. (2004).

\section{Modelling the glacial ocean with an OGCM}

Monthly outputs of the atmosphere model (wind stress, air temperature, net precipitation) from experiments $\mathrm{C}, \mathrm{W}, \mathrm{G}$ and $\mathrm{PD}$ are applied to an improved version of the three-dimensional ocean model LSG (Maier-Reimer et al., 1993), including a third-order QUICK advection scheme (Leonard, 1979; SchäferNeth and Paul, 2001; Prange et al., 2003). The model has 11 vertical levels and a horizontal resolution of $3.5^{\circ}$ on a semi-staggered grid type 'E'. Forcing of the ocean model involves a runoff scheme and a surface heat flux formulation that allows for scale-selective damping of temperature anomalies (Rahmstorf and Willebrand, 1995). It has been demonstrated by Prange et al. (2003) that this hybrid-coupled model approach enables the simulation of observed/reconstructed SSTs as well as the maintenance of large-scale temperature anomalies during freshwater perturbation experiments.

The oceanic equilibrium circulations and hydrographies for the different glacial SST forcings are analysed and discussed in Romanova et al. (2004). Compared to the present-day meridional overturning circulation of the Atlantic Ocean (experiment PD), the glacial
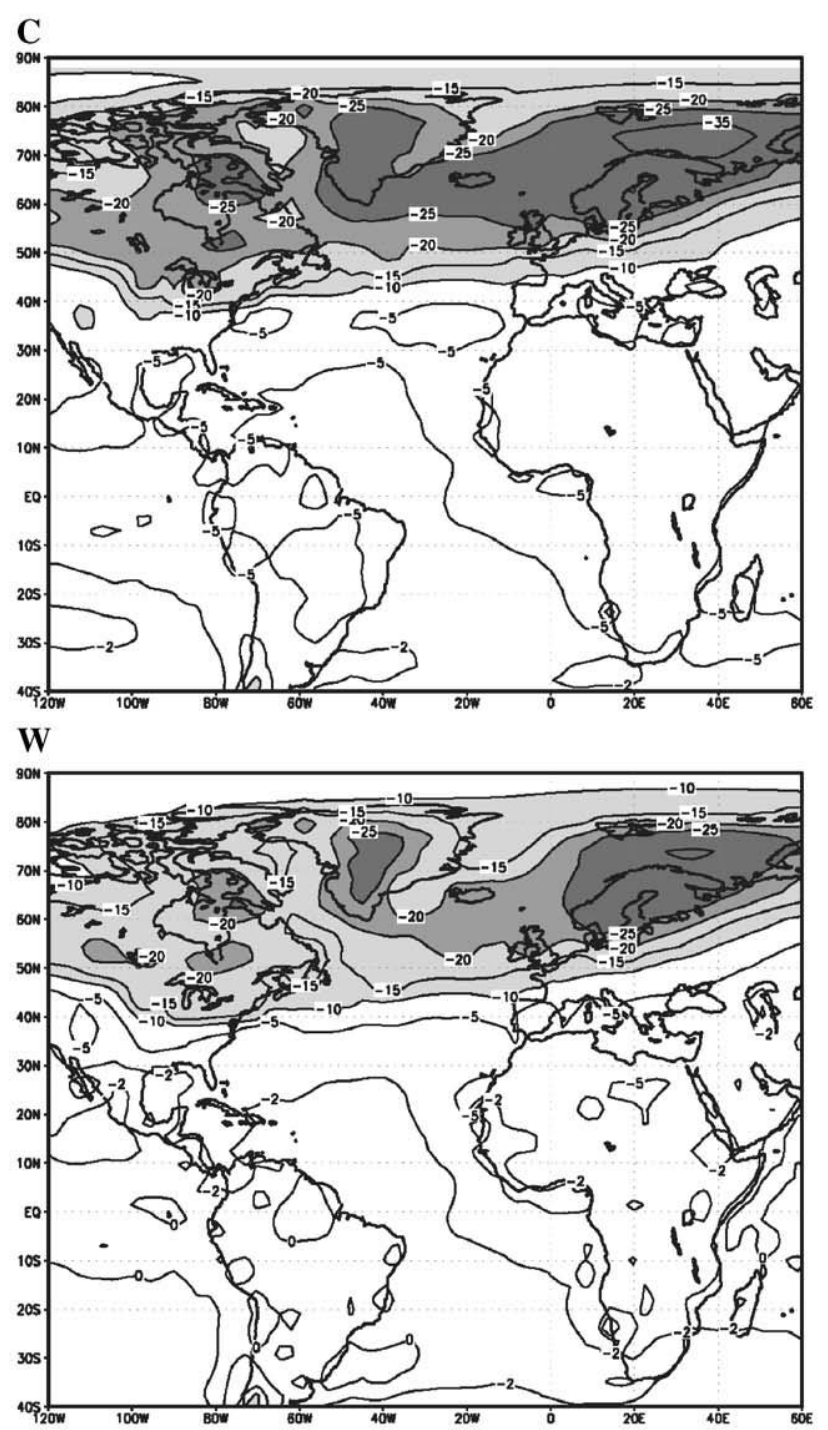

G

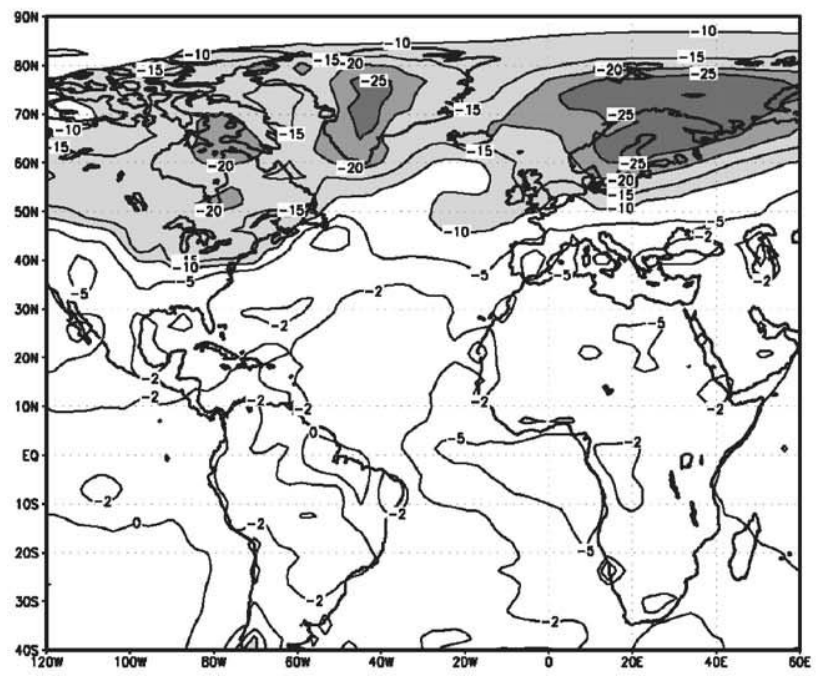

Fig. 1. Differences between glacial and present-day (experiment PD) mean surface air temperatures for experiments $\mathrm{C}, \mathrm{W}$ and $\mathrm{G}$ in the Atlantic realm. Units are in ${ }^{\circ} \mathrm{C}$. 

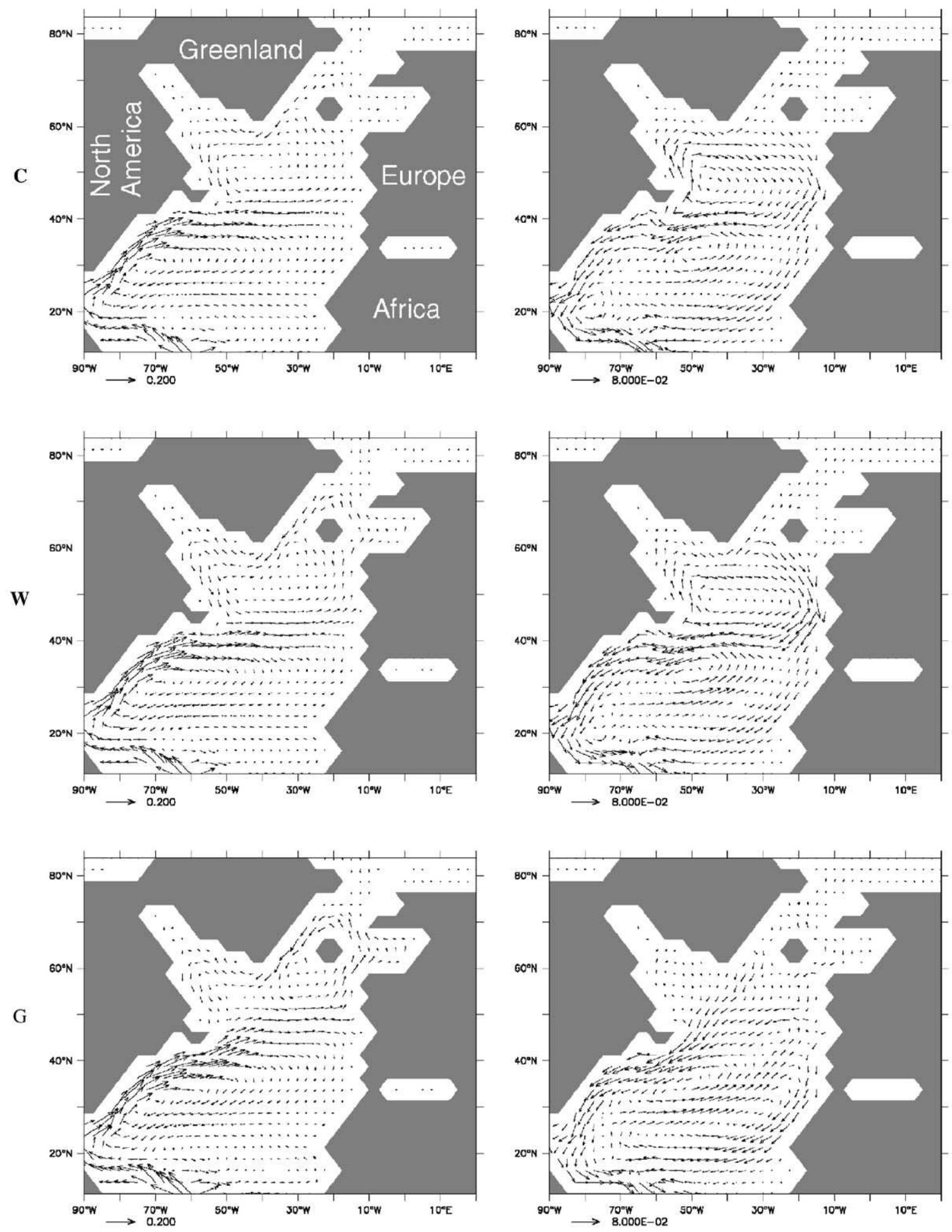

(a)

(b)

Fig. 2. (a) Equilibrium upper ocean circulation (averaged over $0-100 \mathrm{~m}$ ) in the North Atlantic for the glacial experiments $\mathrm{C}$, W and G; (b) annual mean velocity anomalies (averaged over $0-100 \mathrm{~m}$ ) induced by the meltwater perturbation in experiments $\mathrm{C}$, W and $\mathrm{G}$ at year 500 (cf. Fig. 3). Units are in $\mathrm{m} \mathrm{s}^{-1}$.

equilibrium is about $20 \%$ weaker in experiment $\mathrm{C}$, but stronger in the experiments $\mathrm{W}$ and $\mathrm{G}$ (see Fig. 3 prior to year 0 ). In the simulation of the present climate, the major northern hemisphere convection sites are located in the Nordic Seas and in the Labrador Sea (Prange et al., 2003). Due to expanded winter sea-ice covers and more zonal wind stresses, convection sites are shifted southward in the glacial experiments, thus deep water is 
entirely formed in the North Atlantic south of $65^{\circ} \mathrm{N}$ (Romanova et al., 2004). Consequently, the 'conveyor' extends further to the north in experiment PD than in the glacial experiments.

Fig. 2a shows the surface circulation in the North Atlantic/Nordic Seas for the glacial climates. In experiment $\mathrm{C}$, meridional velocities are very small north of $40^{\circ} \mathrm{N}$ and the North Atlantic Current (NAC) turns out to be a zonal stream. The subpolar gyre is more vigorous in experiment $\mathrm{W}$ with a significant inflow to the Nordic Seas. The surface circulation in experiment $\mathrm{G}$ resembles the present-day flow pattern, including a strong northward component of the NAC.

\section{Meltwater perturbation experiments}

The equilibrium states are perturbed by a sudden 500year freshwater input to the North Atlantic, uniformly applied between $40^{\circ} \mathrm{N}$ and $55^{\circ} \mathrm{N}$. A relatively high freshwater influx of $0.5 \mathrm{~Sv}\left(0.5 \times 10^{6} \mathrm{~m}^{3} \mathrm{~s}^{-1}\right)$ has been chosen to ensure a complete and rapid shutdown of the THC in all experiments, making direct comparison of the resulting temperature anomaly fields easier.

The temporal response of the Atlantic THC to the freshwater input is plotted in Fig. 3. After termination of the anomalous freshwater forcing, the present-day circulation remains in the 'off' mode, whereas the glacial circulations recover spontaneously with different rates. The different stability behaviour is linked to the Atlantic freshwater budgets. In experiment $\mathrm{C}$, the net atmospheric moisture export out of the Atlantic catchment area $\left(>30^{\circ} \mathrm{S}\right.$, Arctic Ocean included) is $0.08 \mathrm{~Sv}$ greater than in experiment PD. The lack of a low-saline Bering Strait throughflow, owing to a lowered sea level, leads to a further reduction in the freshwater supply to the

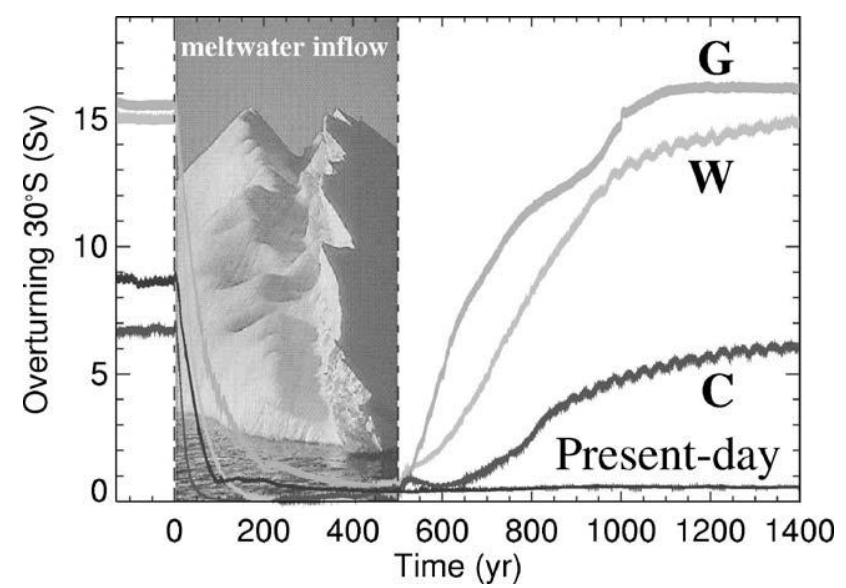

Fig. 3. Temporal evolution of the Atlantic meridional overturning circulation (here: net export of North Atlantic deep water at $30^{\circ} \mathrm{S}$ ) in the experiments C, W, G and PD. A 500-yr meltwater perturbation is applied at year 0 . In experiment PD the circulation remains in the 'off' mode after termination of the meltwater input. glacial North Atlantic (Prange et al., 2002). In experiments $\mathrm{W}$ and $\mathrm{G}$, moisture exports out of the Atlantic are even higher than in experiment $\mathrm{C}(+0.17$ and $+0.38 \mathrm{~Sv}$, respectively, relative to experiment $\mathrm{PD}$ ). As a result, the THC resides in the so-called 'thermohaline flow regime' (Rahmstorf, 1996) in all glacial experiments (Romanova et al., 2004). In this flow regime, freshwater is carried northward by the conveyor's upper limb into the regions of deep-water formation. Consequently, a circulation with reduced overturning is unstable, since net evaporation over the Atlantic and wind-driven oceanic salt transports would inevitably enhance North Atlantic salinities, driving convection and the THC. This mechanism works most efficiently in experiment $G$, where net evaporation is largest. By way of contrast, the present-day conveyor is driven by heat loss with freshwater forcing braking the overturning (so-called 'thermal flow regime'), thus allowing for multiple equilibria (Stommel, 1961; Rahmstorf, 1996).

Fig. 4 shows the response of Atlantic surface temperatures to the freshwater perturbation for the glacial and the present-day experiments. In experiment $\mathrm{PD}$, the strongest cooling occurs in the northern North Atlantic and the Nordic Seas, where SSTs decrease by more than $5^{\circ} \mathrm{C}$, consistent with other meltwater experiments for the present-day climate (e.g., Manabe and Stouffer, 1995; Rahmstorf, 1995; Schiller et al., 1997). In the glacial experiments, the cooling is restricted to lower latitudes. A salient temperature drop appears in the eastern North Atlantic off Portugal in experiments C and $\mathrm{W}$. Alkenone data suggest that pronounced cooling off the Iberian peninsula in the order of $3-6^{\circ} \mathrm{C}$ is indeed a typical feature of Heinrich Events (Bard et al., 2000; Pailler and Bard, 2002; Rühlemann, unpublished). This cooling can best be explained by looking at the flow anomalies induced by the freshwater input in the upper Atlantic (Fig. 2b). In both experiments $\mathrm{C}$ and $\mathrm{W}$, a strong anomalous southward flow emerges in the eastern North Atlantic from Iceland to Cape Blanco, which is associated with anomalous advection of cold water from the North. In experiment G, the anomalous southward current in the eastern Atlantic is confined between latitudes $40^{\circ} \mathrm{N}$ and $20^{\circ} \mathrm{N}$, reflecting a pure intensification of the Canary Current. The same holds for experiment PD (not shown).

In the South Atlantic, pronounced warming at about $40^{\circ} \mathrm{S}$ and off the coast of Namibia is detected for all climatic background states considered (Fig. 4). Both regional features are explored in the coupled AGCM/ OGCM study of Lohmann (2003). The warming at $40^{\circ} \mathrm{S}$ is linked to an anomalous southward flow along the coast of South America which turns to the east at about $40^{\circ} \mathrm{S}$. The strong warming off Namibia is associated with a reduced northward flow and more horizontal isotherms. Equatorial surface warming occurs only in experiment $\mathrm{G}$ (Fig. 4). 
C

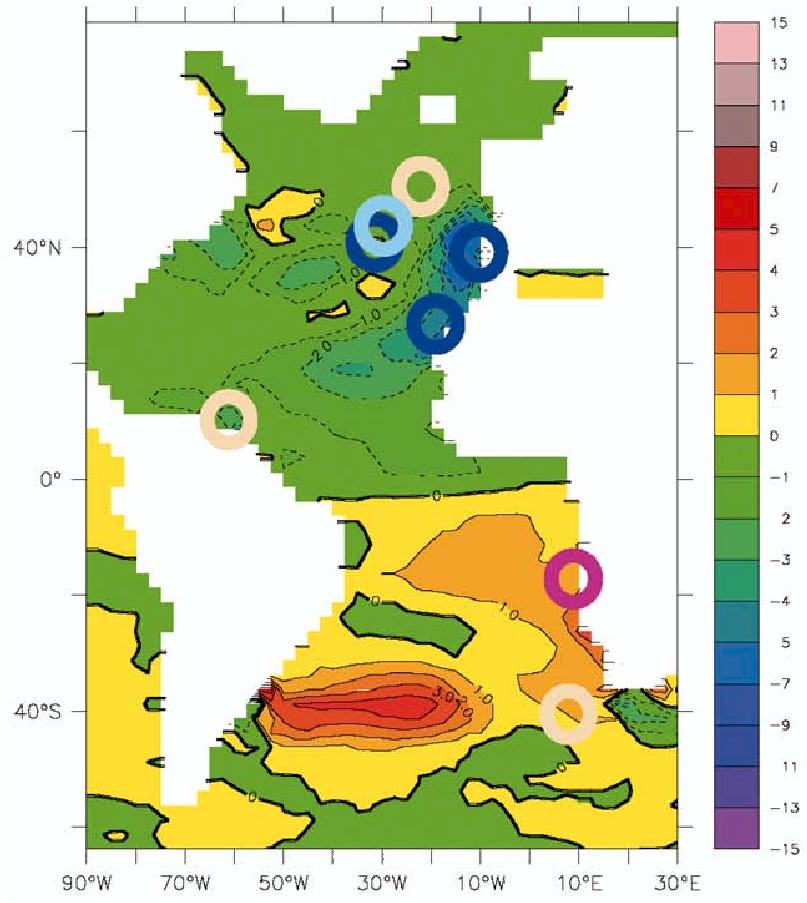

G

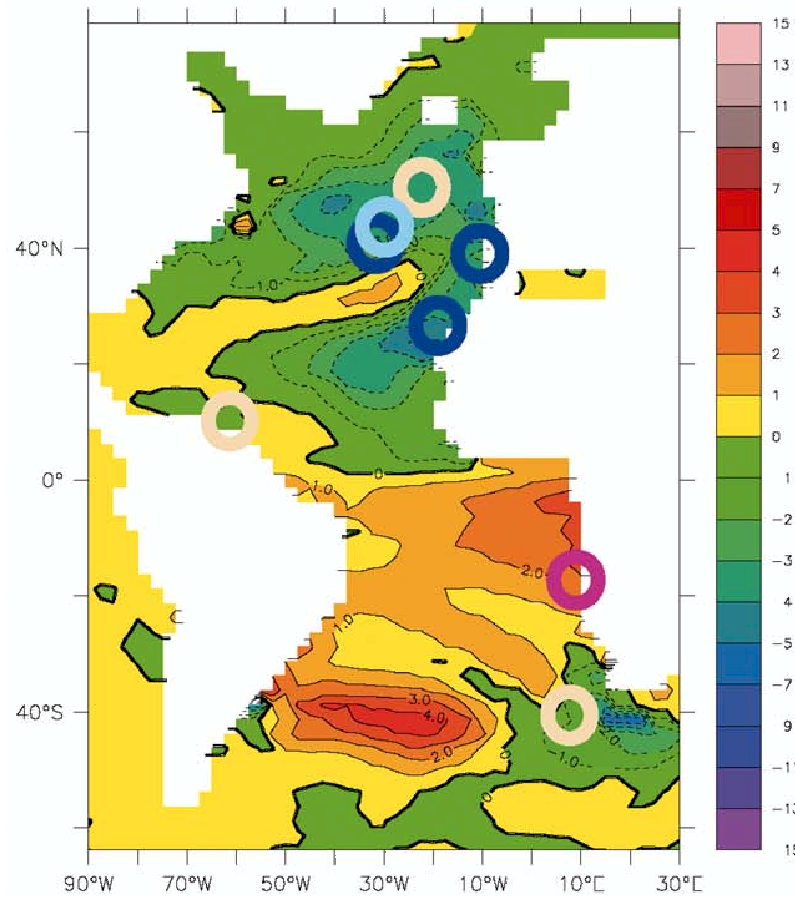

W

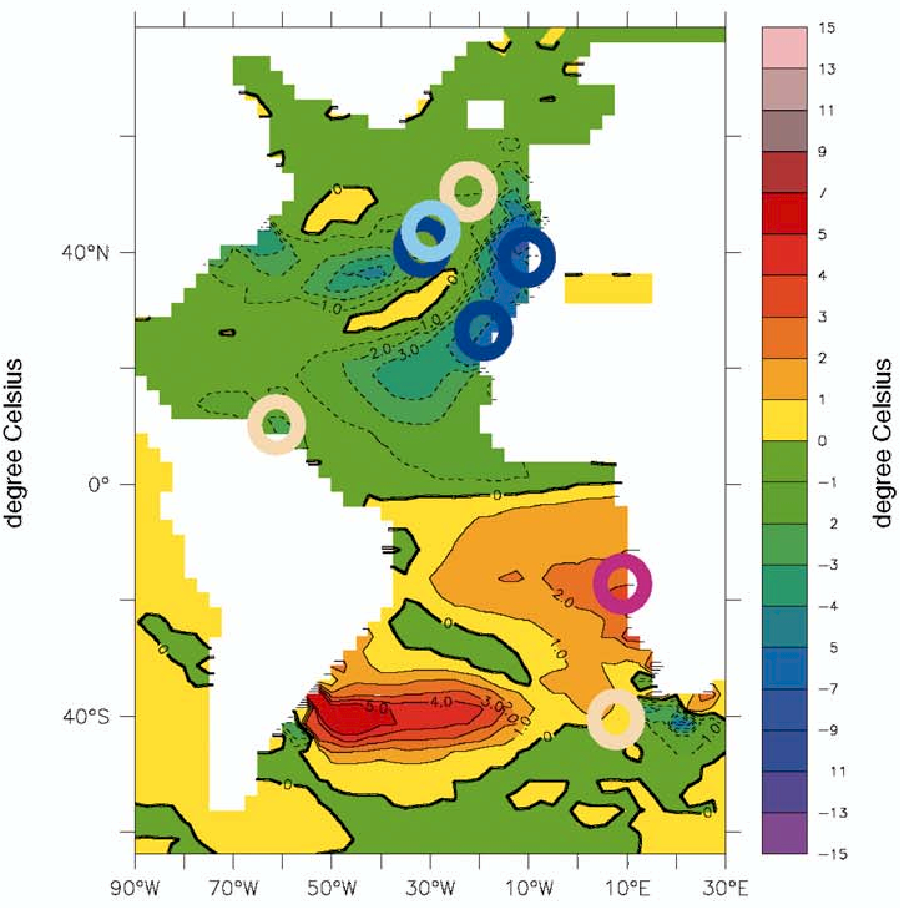

PD

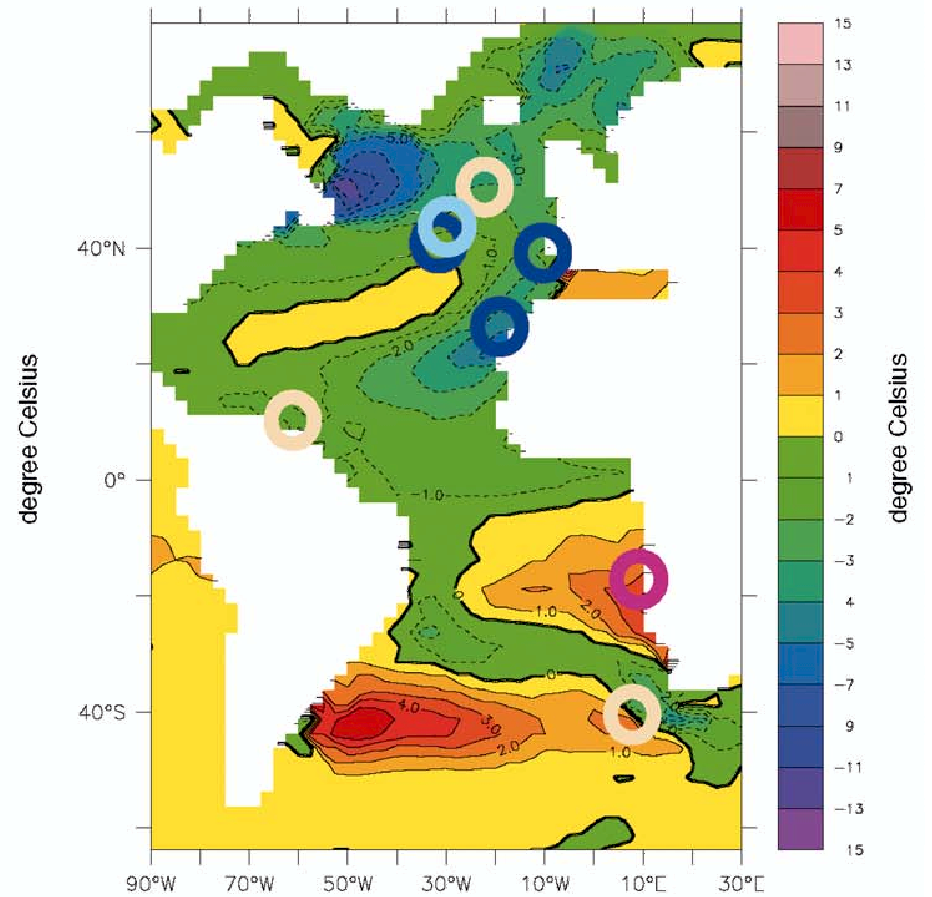

Fig. 4. Atlantic SST response to the meltwater perturbation in experiments $\mathrm{C}, \mathrm{W}, \mathrm{G}$ and PD. Temperature anomalies relative to the unperturbed equilibria are plotted at the end of the meltwater period (i.e., at year 500). For comparison, temperature changes suggested by proxy data from marine sediment cores for Heinrich Event 1 are marked by circles as follows: warming (violet red), temperature changes less than $\pm 0.5^{\circ} \mathrm{C}$ (beige), cooling (light blue), very strong $\left(>2^{\circ} \mathrm{C}\right.$ ) cooling (dark blue). See Table 1 for references (Cores SO 75-26KL, SU 81-18 and MD 992341 are represented by one circle).

The model results can be compared with palaeoceanographic data from the Atlantic Ocean. Some highresolution marine sediment cores which provide infor- mation about SST changes during Heinrich Event 1 (around $16 \mathrm{kyr}$ BP) are compiled in Table 1 and marked in Fig. 4 by coloured circles. The data-model 
Table 1

Some high-resolution marine sediment cores that provide information about SST changes during Heinrich Event 1 in the Atlantic Ocean (from north to south)

\begin{tabular}{|c|c|c|c|}
\hline Core & Position & Method & Reference \\
\hline BOFS $5 \mathrm{~K}$ & $51^{\circ} \mathrm{N}, 22^{\circ} \mathrm{W}$ & Faunal & Maslin et al. (1995) \\
\hline SU 90-08 & $43^{\circ} \mathrm{N}, 30^{\circ} \mathrm{W}$ & Faunal & Paterne et al. (1999) \\
\hline SU 90-03 & $41^{\circ} \mathrm{N}, 32^{\circ} \mathrm{W}$ & Faunal & $\begin{array}{l}\text { Chapman and } \\
\text { Shackleton (1998) }\end{array}$ \\
\hline SO $75-26 \mathrm{KL}$ & $38^{\circ} \mathrm{N}, 10^{\circ} \mathrm{W}$ & Faunal & Zahn (1997) \\
\hline SU $81-18$ & $38^{\circ} \mathrm{N}, 10^{\circ} \mathrm{W}$ & Alkenone & Bard et al. (2000) \\
\hline MD 992341 & $37^{\circ} \mathrm{N}, 8^{\circ} \mathrm{W}$ & Alkenone & $\begin{array}{l}\text { Rühlemann } \\
\text { (unpublished) }\end{array}$ \\
\hline $15637-1$ & $27^{\circ} \mathrm{N}, 19^{\circ} \mathrm{W}$ & Faunal & Kiefer (1998) \\
\hline M 35003-4 & $12^{\circ} \mathrm{N}, 61^{\circ} \mathrm{W}$ & Alkenone & $\begin{array}{l}\text { Rühlemann et al. } \\
\text { (1999) }\end{array}$ \\
\hline GeoB $1023-5$ & $17^{\circ} \mathrm{S}, 11^{\circ} \mathrm{E}$ & Alkenone & Kim et al. (2002) \\
\hline TN 057-21-PC2 & $41^{\circ} \mathrm{S}, 8^{\circ} \mathrm{E}$ & Alkenone & Sachs et al. (2001) \\
\hline
\end{tabular}

Faunal and alkenone reconstructions are considered. The cores are marked in Fig. 4 by coloured circles

comparison reveals that the overall spatial signature of SST anomalies is captured much better in the glacial experiments than in experiment PD. In particular, note the behaviour of the three northernmost cores, BOFS $5 \mathrm{~K}, \mathrm{SU}$ 90-08 and SU 90-03, which indicates a reduced meridional SST gradient during the Heinrich Event in northern mid-latitudes (cf. Chapman and Maslin, 1999). This behaviour is captured only in experiments $\mathrm{C}$ and $\mathrm{W}$.

\section{Conclusions}

Our hybrid-coupled model approach has been successfully employed in previous palaeostudies (Prange et al., 2002; Knorr and Lohmann, 2003; Rühlemann et al., 2003; Romanova et al., 2004). It is a comparatively simplified climate model which omits changes in atmosphere dynamics; that is, wind stresses remain unaffected during the perturbation experiments. Therefore, SST changes in our experiments are solely induced by variations in large-scale oceanic heat transports. We find that the SST response for present-day conditions is similar to experiments using coupled AGCM/OGCMs (e.g., Manabe and Stouffer, 1995; Lohmann, 2003). The main advantage of the hybrid-coupled approach is that palaeoceanographic reconstructions and modern observations can directly be 'assimilated' into the model. Our results reveal that the Atlantic SST response to meltwater perturbations strongly depends on the applied background climatology. Hence, simulations of Heinrich Events are challenging, not only because of many unknowns of the iceberg-meltwater forcing (magnitude, duration, location), but also because of uncertainties concerning the glacial 'basic state'. Nevertheless, all glacial experiments conducted capture important features of the Heinrich Event SST signature found in palaeoceanographic records, like an extreme cooling off Iberia.

Palaeoclimatic evidence shows that Heinrich Events had a strong impact on global climate during the last glacial period (e.g., Broecker and Hemming, 2001), probably even affecting the evolution of mankind. A recent study by d'Errico and Sánchez Goñi (2003) suggests that inhospitable environmental conditions during Heinrich Event 4 (around 39kyr BP) favoured the persistence of the last Neanderthal populations in southern Iberia, where the replacement by anatomically modern humans took place only after the cold event. Our model experiments indicate that a breakdown of the present-day THC would induce even stronger climatic changes in the North Atlantic realm than did Heinrich Events during the ice age. Furthermore, our results suggest that the modern circulation can settle into a stable 'off' mode, whereas the glacial THC always recovered spontaneously as soon as anomalous freshwater inputs disappeared.

\section{Acknowledgements}

We thank Stefan Mulitza, Carsten Rühlemann and Mark Maslin for helpful suggestions. This research was funded by the Bundesministerium für Bildung und Forschung (BMBF) through DEKLIM and by the Deutsche Forschungsgemeinschaft as part of the DFG Research Center 'Ocean Margins' of the University of Bremen (No. RCOM0095).

\section{References}

Bard, E., Rostek, F., Turon, J.-L., Gendreau, S., 2000. Hydrological impact of Heinrich events in the subtropical Northeast Atlantic. Science 289, 1321-1324.

Broecker, W.S., Hemming, S., 2001. Climate swings come into focus. Science 294, 2308-2309.

Bryan, F., 1986. High-latitude salinity effects and interhemispheric thermohaline circulations. Nature 323, 301-304.

Chapman, M.R., Shackleton, N.J., 1998. Millennial-scale fluctuations in North Atlantic heat flux during the last 150,000 years. Earth and Planetary Science Letters 159, 57-70.

Chapman, M.R., Maslin, M.A., 1999. Low-latitude forcing of meridional temperature and salinity gradients in the subpolar North Atlantic and the growth of glacial ice sheets. Geology 27, 875-878.

Clark, P.U., Pisias, N.G., Stocker, T.F., Weaver, A.J., 2002. The role of the thermohaline circulation in abrupt climate change. Nature 415, 863-869.

CLIMAP (Project Members), 1981. Seasonal reconstructions of the Earth surface at the Last Glacial Maximum. Geological Society of America, Map and Chart Series, MC-36, Boulder, Col., 18 maps.

Crucifix, M., Tulkens, P., Berger, A., 2001. Modeling abrupt climatic change during the last glaciation. In: Seidov, D., Haupt, B.J., Maslin, M. (Eds.), The Oceans and Rapid Climate Change-Past, 
Present and Future. Geophysical Monographs. 126, American Geophysical Union, Washington, DC, pp. 117-134.

d'Errico, F., Sánchez Goñi, M.F., 2003. Neandertal extinction and the millennial scale climatic variability of OIS 3. Quaternary Science Reviews 22, 769-788.

Ganopolski, A., Rahmstorf, S., 2001. Rapid changes of glacial climate simulated in a coupled climate model. Nature 409, 153-158.

Kiefer, T., 1998. Produktivität und Temperaturen im subtropischen Nordatlantik: zyklische und abrupte Veränderungen im späten Quartär. Geologisch Paläontologisches Institut Universitat Kiel, Berichte-Reports 90, Kiel, Germany, 127pp.

Kim, J.-H., Schneider, R.R., Müller, P.J., Wefer, G., 2002. Interhemispheric comparison of deglacial sea-surface temperature patterns in Atlantic eastern boundary currents. Earth and Planetary Science Letters 194, 383-393.

Knorr, G., Lohmann, G., 2003. Southern Ocean origin for the resumption of Atlantic thermohaline circulation during deglaciation. Nature 424, 532-536.

Leonard, B.P., 1979. A stable and accurate convective modelling procedure based on quadratic upstream interpolation. Computational Methods Applied Mechanics and Engineering 19, 59-98.

Lohmann, G., 2003. Atmospheric and oceanic freshwater transport during weak Atlantic overturning circulation. Tellus 55A, 438-449.

Lohmann, G., Lorenz, S., 2000. On the hydrological cycle under paleoclimatic conditions as derived from AGCM simulations. Journal of Geophysical Research 105, 17417-17436.

Lohmann, G., Gerdes, R., Chen, D., 1996. Sensitivity of the thermohaline circulation in coupled oceanic GCM-atmospheric EBM experiments. Climate Dynamics 12, 403-416.

Maier-Reimer, E., Mikolajewicz, U., 1989. Experiments with an OGCM on the cause of the Younger Dryas. MPI Report 39, Hamburg, Germany, 13pp.

Maier-Reimer, E., Mikolajewicz, U., Hasselmann, K., 1993. Mean circulation of the Hamburg LSG OGCM and its sensitivity to the thermohaline surface forcing. Journal of Physical Oceanography 23, 731-757.

Manabe, S., Stouffer, R.J., 1995. Simulation of abrupt climate change induced by freshwater input to the North Atlantic Ocean. Nature 378, 165-167.

Maslin, M.A., Shackleton, N.J., Pflaumann, U., 1995. Surface water temperature, salinity and density changes in the northeast Atlantic during the last 45,000 years: Heinrich Events, deep water formation, and climatic rebounds. Paleoceanography 10, 527-544.

Pailler, D., Bard, E., 2002. High frequency paleoceanographic changes during the past 140,000 years recorded by the organic matter in sediments of the Iberian Margin. Palaeogeography, Palaeoclimatology, Palaeoecology 181, 431-452.

Paterne, M., et al., 1999. Hydrological relationship between the North Atlantic Ocean and the Mediterranean Sea during the past 15-75 kyr. Paleoceanography 14, 626-638.

Paul, A., Schäfer-Neth, C., 2003. Modeling the water masses of the Atlantic Ocean at the Last Glacial Maximum. Paleoceanography 18, doi: $10.1029 / 2002$ PA000783.

Peltier, W.R., 1994. Ice age paleotopography. Science 265, 195-201.

Prange, M., Romanova, V., Lohmann, G., 2002. The glacial thermohaline circulation: Stable or unstable? Geophysical Research Letters 29, 2028 (doi:10.1029/2002GL015337).
Prange, M., Lohmann, G., Paul, A., 2003. Influence of vertical mixing on the thermohaline hysteresis: analyses of an OGCM. Journal of Physical Oceanography 33, 1707-1721.

Rahmstorf, S., 1995. Bifurcations of the Atlantic thermohaline circulation in response to changes in the hydrological cycle. Nature 378, 145-149.

Rahmstorf, S., 1996. On the freshwater forcing and transport of the Atlantic thermohaline circulation. Climate Dynamics 12, 799-811.

Rahmstorf, S., Willebrand, J., 1995. The role of temperature feedback in stabilizing the thermohaline circulation. Journal of Physical Oceanography 25, 787-805.

Rind, D., et al., 2001. Effects of glacial meltwater in the GISS coupled atmosphere-ocean model: Part I: North Atlantic deep water response. Journal of Geophysical Research 106, 27335-27353.

Roeckner, E., et al., 1992. Simulation of the present-day climate with the ECHAM model: Impact of model physics and resolution. MPI Report 93, Hamburg, Germany, 171pp.

Romanova, V., Prange, M., Lohmann, G., 2004. Stability of the glacial thermohaline circulation and its dependence on the background hydrological cycle. Climate Dynamics, in press.

Rühlemann, C., Mulitza, S., Müller, P.J., Wefer, G., Zahn, R., 1999. Warming of the tropical Atlantic Ocean and slowdown of thermohaline circulation during the last deglaciation. Nature 402, 511-514.

Rühlemann, C., Mulitza, S., Lohmann, G., Paul, A., Prange, M., Wefer, G., 2003. Abrupt warming of the intermediate-depth Atlantic Ocean in response to thermohaline circulation slowdown during the last deglaciation. PAGES News 11 (1), 17-19.

Sachs, J.P., Anderson, R.F., Lehman, S.J., 2001. Glacial surface temperatures of the southeast Atlantic Ocean. Science 293, 2077-2079.

Sarnthein, M., et al., 2003. Overview of glacial Atlantic Ocean mapping (GLAMAP 2000). Paleoceanography 18 (doi:10.1029/ 2002PA000769).

Schäfer-Neth, C., Paul, A., 2001. Circulation of the glacial Atlantic: a synthesis of global and regional modeling. In: Schäfer, P., Ritzrau, W., Schlüter, M., Thiede, J. (Eds.), The Northern North Atlantic: A changing Environment. Springer, Berlin, Heidelberg, pp. 446-462.

Schiller, A., Mikolajewicz, U., Voss, R., 1997. The stability of the North Atlantic thermohaline circulation in a coupled OAGCM. Climate Dynamics 13, 325-347.

Stocker, T.F., Wright, D.G., 1991. Rapid transitions of the ocean's deep circulation induced by changes in surface water fluxes. Nature $351,729-732$.

Stommel, H., 1961. Thermohaline convection with two stable regimes of flow. Tellus 13, 224-230.

Weinelt, M., Sarnthein, M., Pflaumann, U., Schulz, H., Jung, S., Erlenkeuser, H., 1996. Ice-free Nordic Seas during the Last Glacial Maximum? Potential sites of deepwater formation. Palaeoclimates 3, 23-57.

Zahn, R., 1997. North Atlantic thermohaline circulation during the last glacial period: evidence for coupling between meltwater events and convective instability. GEOMAR Report 63, Kiel, Germany, 133pp. 